\title{
URBAN PLANNING DEVELOPMENT AND HISTORICAL DEVELOPMENT IN ANCIENT CENTRAL ASIA
}

\section{Zumradkhon B. Baymetova}

Master Tashkent Institute Of Architecture And Construction Tashkent, Uzbekistan

\section{ABSTRACT}

This article deals with the development of ancient urban planning, its material and spiritual sources, the existence of ancient cultural and material heritage in the heart of our homeland, as well as economic factors in the emergence of cities on the basis of historical facts from primitive society.

KEYWORDS: - Urban planning, archeology, primitive period, handicrafts, art, history of architecture.

\section{INTRODUCTION}

The history of the formation and centuries-old development of Central Asian urban planning has been studied during archeological excavations and scientific research. The history of Central Asian urban planning has evolved over the centuries, from the first settlements based on caves and tents to modern urban planning.

The weakness of providing people with the necessities of life has encouraged people to live and work as a team. They felt that power was in unity, and that power began to teach them the mysteries of nature. This was the basis for them to live as a community and to form settlements. The history of urban planning and architecture of the primitive period covers the period from the understanding and development of human consciousness and emotion to the emergence of the first states in the world.

\section{THE MAIN RESULTS AND FINDINGS}

The historical evidence that has come down to us from the time of primitive society - labor and hunting weapons, household utensils and ornaments, residential areas - material and spiritual sources of urban planning, helps to form an idea of the urban culture of primitive society. Cultural and material monuments in the heart of our motherland, bone remains of human and animal bodies, paintings and reliefs on the walls of caves and basements are the main sources for studying the history of urban planning and architecture of primitive society. Urban planning and architecture emerged and took shape in the 
CURRENT RESEARCH JOURNAL OF HISTORY 2(12): 20-23, December

2021

DOI: https://doi.org/10.37547/history-crjh-02-12-05

ISSN 2767-472X

(C2021 Master Journals

\section{Crossref doi) 8 Google}

Accepted 24th December, 2021 \& Published 29th December, 2021

labor process in the lives of primitive people. The question of where and when the first city on our planet appeared still remains unanswered. The emergence and formation of habitats necessary for human life has been going on for centuries to the present day, and on this basis urban planning is developing.

At a time when the first cities were beginning to take shape as a major part of human activity, the profession developed as a result of the division of labor in society. Military fortifications (fortified cities) began to appear to protect the city from external factors that hindered its development. Trade, handicrafts, art, and architecture began to take shape in the cities with strong protection. Over the centuries, the development of cities has changed its appearance, quality and form based on the needs and requirements of society. The formed city developed in conditions conducive to the lifestyle and way of life of the society. In addition to social and functional conditions, the geographical environment and climate have also become an important factor in the formation and development of the city. The geographical environment has a great influence on the development of society and at the same time on the formation and development of the city. Because in order to live, to cultivate, you definitely need fertile land and water. That is why cities are located in fertile lands near rivers and streams. Geographical environment, i.e. various features of natural conditions can have a strong impact on the formation of the environment, which can accelerate or slow down its development.
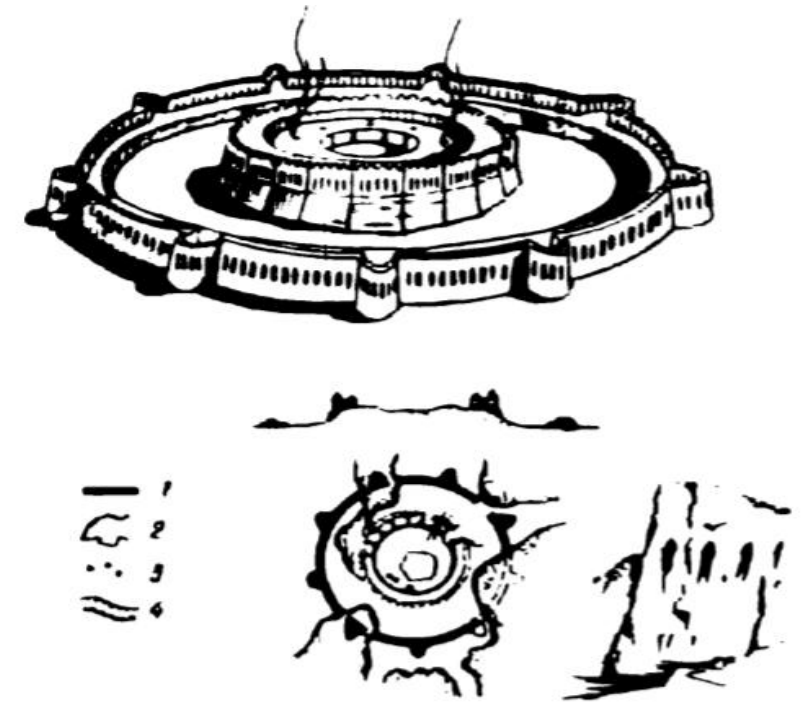

The main economic factor in the formation of ancient city-states was the agriculture and handicrafts of the settled population, which were initially the economic center of the surrounding settlements, the center of social management of political, religious and self-governing stratified communities of a district, region or country. which was. The formation of cities is historically based on the economic life of society and the existence of three other factors associated with it.

The first is favorable natural conditions, i.e. fertile soil, water and other geographical factors; the second is productive irrigated agriculture and the agro-techniques that provide it. These are the economic factors in the emergence of cities; Thirdly, conditions must be created for the emergence of a system of religious, military and political governance of a differentiated society based on these economic factors, ie radical changes in economic life (discovery of artificial irrigation systems in agriculture, pumping water from rivers through large canals, land use of hammers and animals in work, the discovery of spinning and weaving machines in the textile 
CURRENT RESEARCH JOURNAL OF HISTORY 2(12): 20-23, December

2021

DOI: https://doi.org/10.37547/history-crjh-02-12-05

ISSN 2767-472X

(C2021 Master Journals

\section{Crossref doi gil Google}

Accepted 24th December, 2021 \& Published 29th December, 2021

industry, the discovery of wheels and intricate jars in ceramics, the discovery of metal melting and casting methods, the use of pets in transport, the construction of houses and monumental buildings, on the basis of accumulated knowledge about the environment (astronomy, astrology, sundial, calendar, the invention of a complex computing system, etc.) due to stratification in social life. Once this stratification process reaches a certain point, the need arises to govern society. It was a social factor. When these three factors are sufficiently ensured to coexist, and only when the historical conditions for this are born, the

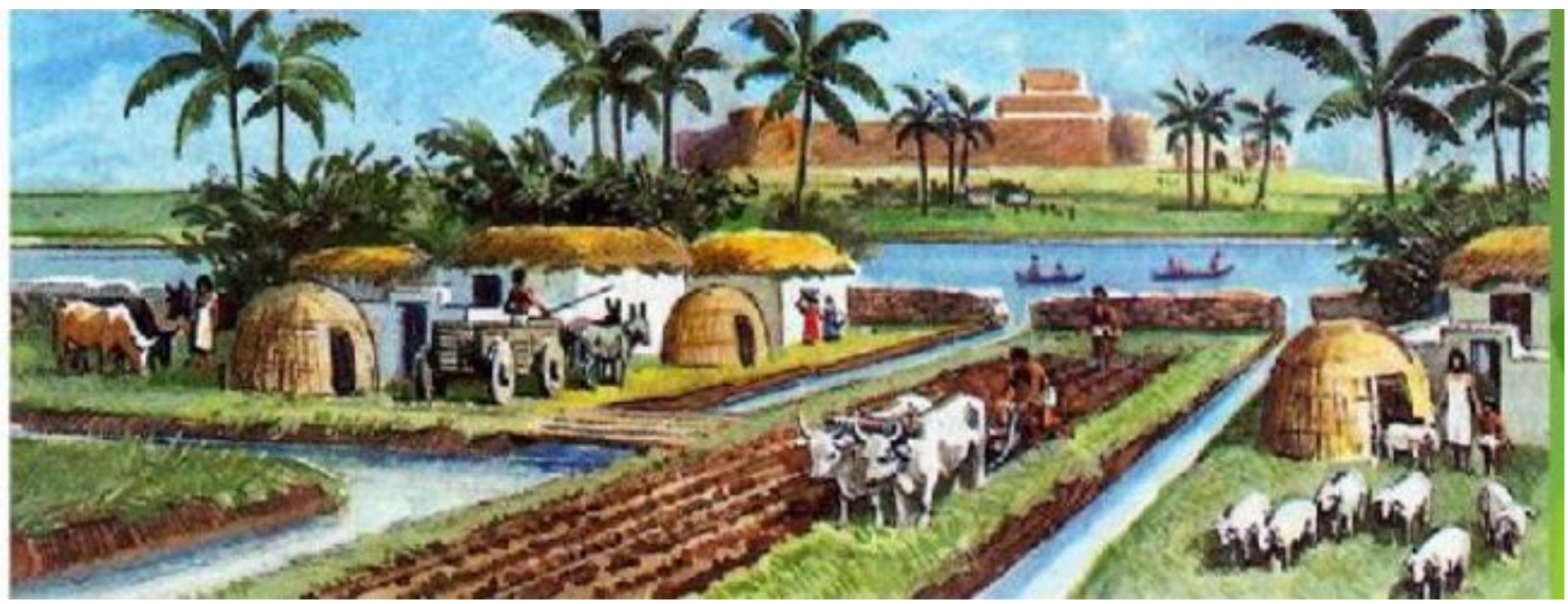

ancient cities and the city-states on their basis will appear. The above three factors were sufficient for the early formation and formation of the ancient cities of Central Asia. According to scientific sources, the existence of important factors for the life of a society is required for a place of residence to be called a city.

That is, the city area is densely populated with 5 6 people, the settlements are protected from external influences by strong defensive walls on all sides, the settlements of the upper classes and mayors are separated from ordinary settlements, the mayor's residence is located on a high foundation (high hill). the monumental palace, the city community area, ie the holy religious center in Shahristan, which serves all segments of the city population, has a magnificent temple, the economic basis of the city is diversified crafts and trade, availability and a number of other factors are indicated in the naming of settlements as cities. The lands of Central Asia have been a source of life for centuries since time immemorial. The process of the division of the globe into terrestrials, as well as the formation of the flora and fauna, had its own characteristics in these countries as well. In particular, scientists have determined that the Fergana Valley and the Aral Sea basin are rich in flora and fauna during the period when the seas dried up and lands appeared 40-20 million years ago. Many scholars note that a number of small settlements (inhabited by 50-300 people) in the V-VI millennium BC, such as Qoratepa, Koksuv, inhabited by 100-200 people. In the III millennium BC, the settlements of Oltintepa and Namozgohtepa were inhabited by 500-10000 people, and centers of blacksmithing and pottery were established. By this time, two rows of pottery and a pottery wheel appear. In Central 
CURRENT RESEARCH JOURNAL OF HISTORY 2(12): 20-23, December

2021

DOI: https://doi.org/10.37547/history-crjh-02-12-05

ISSN 2767-472X

(C2021 Master Journals

\section{Crossref doi) 8 Google}

Accepted 24th December, 2021 \& Published 29th December, 2021

Asia, the first primitive societies of the Ancient East began to form. This indicates the formation of the state. Gradually, the religious worldview begins to take shape. For example, the fourtiered tower in Altintepa, $12 \mathrm{~m}$ high and $28 \mathrm{~m}$ long, at first glance resembles the Mesopotamian stepped towers - ziggurats. In general, Oltintepa culture has a great artistic character. At the same time, tin was brought to Central Asia from the lands of present-day Afghanistan, and ways to form a bronze (bronze-brass) alloy were discovered, and its strength was determined more than that of copper. The discovery of bronze, the emergence of peasantry and aristocracy all led to the division of early social labor. This, in turn, leads to the formation of slavery relations and the formation of a class society. The end of the 2 nd millennium $\mathrm{BC}$ and the beginning of the 1st millennium $\mathrm{BC}$ are marked by the emergence of slavery in Central Asian history. In the lower reaches of the Amu Darya, in the Fergana Valley and in the Zarafshan oasis, the settlements of tribes engaged in animal husbandry are known. Until now, camels were known as pets, but now horses are being used for the same purpose. Studies have shown that in the 10 th and 7 th centuries BC, a number of tools were made of iron and large irrigation facilities were built. It was at this time that the first state buds based on slavery began to emerge. Land and property disputes with each other result in wars between tribes and enslavement of people on the defeated side. The result is a certain nation-slave and his ruler god. This leads to a crushing and crushing class relationship. By this time, irrigated farming lands were expanding to the north, and the first associations in the formation of the first statehood were formed. In northern Central Asia and eastern Iran, fire was considered sacred in the early 1 st millennium BC and spread to other parts of Media and Persia a few hundred years later.

\section{Conclusion}

It is believed that the Avesto, the holy book of firefighters, began to be written at this time (10th-4th centuries BC). Because it does not mention the centralized Iranian state formed in the second half of the VI century BC. A number of lands are formed in the basins of the Atrek, Gurgan, Kunduz, Murgab, Amudarya and Zarafshan rivers. In the X-VI centuries $\mathrm{BC}$, the ancient Girhoniya (on the south-eastern shores of the Caspian Sea), Parthia (in the south of present-day Turkmenistan), formed their own provinces. There is also information about the ancient Fergana (Parakan - Parkanus in the commentary of Greek historians) and the ancient Khorezm countries. According to Abu Rayhan Beruni, ancient Khorezm was a centralized state with its own state language and yearbook. It was the 10th century according to the local calendar when Greek-Macedonian troops led by Alexander the Great (or Macedonian and again Alexander the Great of the 4th century BC) invaded.

\section{REFERENCES}

1. Maotinson T. G. In search of the ancient lakes of Asia. L .: "Science", 1989, p. 155

2. Masson V.M. Central Asia in the III-I millennia BC e., History of the Ancient East. M .: "High school", 1988, p. 283, 290.

3. History of the Uzbek SSR (from the earliest times to the present day). Tashkent: Fan. 1974 , p. nineteen.

4. Tolstov S. P. Ancient Khorezm. M .: Moscow State University, 1948, p. 59-66. 